\title{
INTERFERENCE OF VOLUNTEER CORN IN GLYPHOSATE RESISTANT SOYBEAN AND CHEMICAL CONTROL IN DIFFERENT PHENOLOGICAL STAGES
}

\author{
INTERFERÊNCIA DO MILHO VOLUNTÁRIO NA SOJA RESISTENTE AO \\ GLIFOSATO E CONTROLE QUÍMICO EM DIFERENTES ESTÁDIOS \\ FENOLÓGICOS
}

\author{
Mariane PERTILE ${ }^{1}$; Joanei CECHIN²; Vinicius ZIMMER ${ }^{2}$; Dirceu AGOSTINETTO²; \\ Leandro VARGAS ${ }^{3}$ \\ 1. Centro de Estudos Superiores de Balsas, CESBA, Universidade Estadual do Maranhão, Balsas, MA, Brasil, \\ mariane_pertile@hotmail.com; 2. Departamento de Fitossanidade, Universidade Federal de Pelotas /UFPel/FAEM, Pelotas, RS, Brasil. \\ 3. Laboratório de Plantas Daninhas, EMBRAPA Trigo, Passo Fundo, RS, Brasil.
}

\begin{abstract}
The successive use of Roundup Ready crops may difficult the management of volunteer plants originated from seed losses during harvest. In soybean, volunteer corn plants can exhibit higher interference and cause reduce yield depending on their density. The aim of this study was to quantify the economic threshold level (ETL) in soybean as a function of the competition of volunteer corn and to evaluate the chemical control in different phenological stages of development. The ETL and chemical control experiments were conducted in the field, under completely randomized and randomized block designs with one and three replicates, respectively. The variables analyzed were yield and ETL as functions of the competition of different volunteer corn populations (control, 1, 2, 4, 6, 8, 10, 12, 16, 20, 24 and 32 plants $\mathrm{m}^{-2}$ ) and the chemical control with acetyl coenzyme-A carboxylase (ACCase) inhibitor herbicides alone or mixed with glyphosate in different phenological stages of development $\left(\mathrm{V}_{2}-\mathrm{V}_{3}, \mathrm{~V}_{4}-\mathrm{V}_{5}\right.$ and $\left.\mathrm{V}_{6}-\mathrm{V}_{8}\right)$ that were evaluated at seven, 14 and 21 days after application (DAA). The results showed higher competitive potential of volunteer corn in which the presence of one plant $\mathrm{m}^{-2}$ reduces the soybean yield in $17 \%$. The ETL ranged from 0.14 to 0.78 plants $\mathrm{m}^{-2}$ and the control of volunteer corn must be carried out in low populations. The use of ACCase inhibitors herbicides alone or mixed with glyphosate demonstrated greater than $85 \%$ control in the $V_{2}-V_{3}$ phenological stage independent of the period evaluated. The effectiveness of all herbicides decreased with application delay with a control level above $87 \%$, in the $\mathrm{V}_{6^{-}}$ $\mathrm{V}_{8}$ phenological stage, obtained only for fluazifop and haloxyfop herbicides alone or in mixed with glyphosate at 14 and 21 days after application.
\end{abstract}

KEYWORDS: Alternative herbicides. Competition. Economic threshold level. Glycine max. Zea mays.

\section{INTRODUCTION}

Corn (Zea mays) and soybean (Glycine max) are the main commercial crops in Brazilian agriculture (CONAB, 2017). The technological advances which occurred for these crops such as the use of glyphosate-resistant crops and the use of integrated agricultural practices constitute factors that provided flexibility, improved weed control, reduced costs and contributed to increased yield (PETTER et al., 2007; BENBROOK, 2016).

Roundup Ready ${ }^{\circledR}$ technology has enabled the selective use of glyphosate in resistant crops for post-emergence spray, simplifying weed management (PETTER et al., 2015). The development of resistance to this herbicide occurred by the insertion of CP4 strain from Agrobacterium sp. responsible for coding one variant of 5enolpyruvylshikimate-3-phosphate synthase enzyme (EPSPs), causing insensitivity to the glyphosate herbicide (PADGETTE et al., 1996). For susceptible plants, the inhibition of EPSPs enzyme blocks the biosynthesis of aromatic amino acids tryptophan, phenylalanine and tyrosine in plastids due structural change at the active site and competition with phosphoenolpyruvate (TAN et al., 2006).

In Brazil, the Roundup Ready corn and soybean are widely used as succession crops in most agricultural areas, resulting in the appearance of glyphosate-resistant volunteer plants from grains lost during harvest (PETTER et al., 2015). The occurrence of volunteer corn plants into soybean fields causes competition for nutrients, light and water, increases control costs owing to the use of alternative herbicides and reduces the yield (DEEN et al., 2006; MARQUARDT et al., 2012). Moreover, volunteer corn plants have early development and $\mathrm{C}_{4}$ cycle allowing for a higher competitive ability compared to soybean, which depends on the relative time of emergence, the origin (individual plant or clump), and the population present in the field (CHADAL; JHALA, 2016), reducing the time to control and the period prior to interference (PPI). 
The presence of volunteer corn plants within another glyphosate-resistant crop impairs the adoption of management strategies reducing the alternatives available for weed control (ALMS et al. 2016). However, the spray of acetyl coenzyme-A carboxylase (ACCase) inhibitor herbicides alone or mixed with glyphosate can be utilized to control volunteer corn (OWEN, 2000) with a reduction of efficacy in function of the differential phenological stage of development (CHADAL et al., 2014). Thus, studies regarding the interference of volunteer corn plants in soybean crops and the effectiveness of alternative controls are important factors that can aid in decision-making processes, reducing costs and protect yield potential.

The aim of this study was to quantify the economic threshold level (ETL) in soybean as a function of the competition of volunteer corn and to evaluate the chemical control in different phenological stages of development.

\section{MATERIAL AND METHODS}

\section{Economic threshold level}

The field experiment was conducted during 2015 in a completely randomized design with one replicate in yellow red Argisol belonging to the Pelotas mapping unit (EMBRAPA, 2013). The soil amendment was performed based on soil analysis following the technical recommendations for soybean (EMBRAPA, 2013). The population of volunteer corn provided the necessary variance to perform the statistical analyzes by the hyperbolic model proposed by Cousens (1985) and ranged from control, 1, 2, 4, 6, 8, 10, 12, 16, 20, 24 and 32 plants $\mathrm{m}^{-2}$. The volunteer corn plants were randomly sown in the plot and conducted without infestation of other weeds during the soybean cycle. The soybean cultivar used was NA 5909 Roundup Ready, using a row spacing of $40 \mathrm{~cm}^{2}$ and population of 36 plants $\mathrm{m}^{-}$ 2. The emergence of volunteer corn and soybean occurred four to five days after sowing and, the environmental conditions are shown in Figure 1.

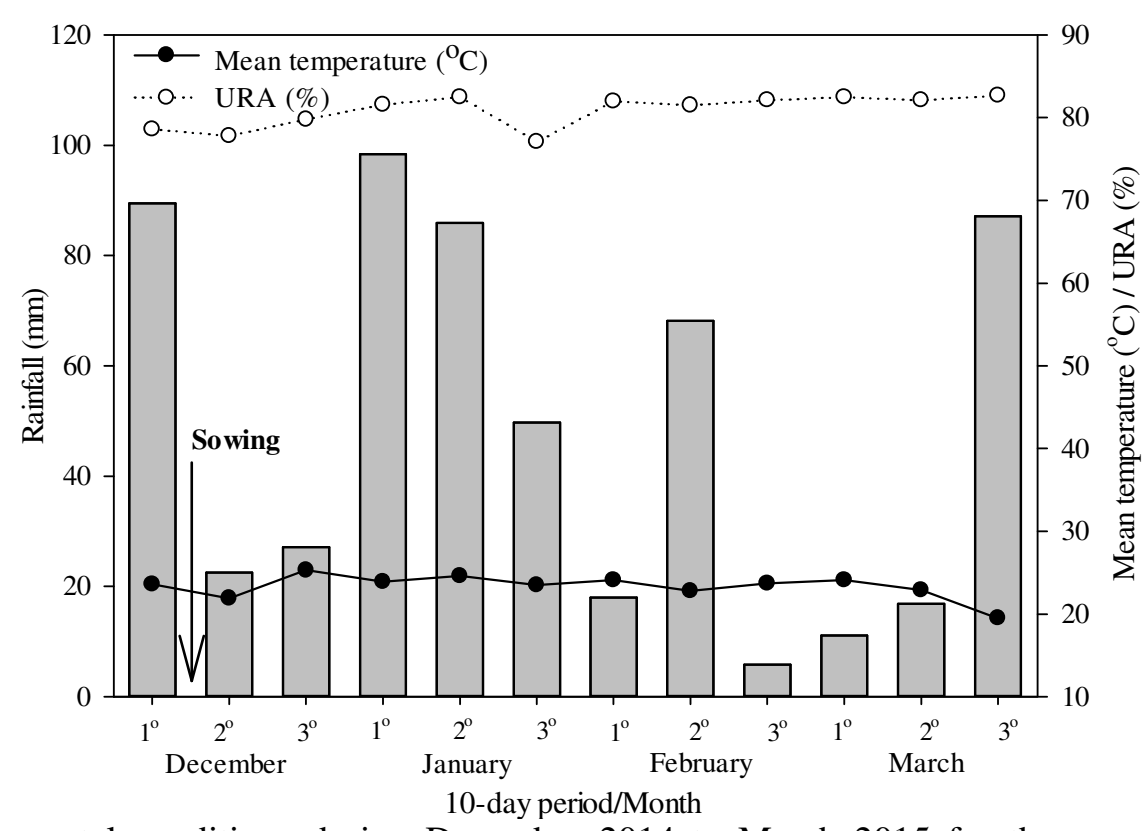

Figure 1. Environmental conditions during December 2014 to March 2015 for the experiment of soybean submitted to competition with volunteer corn.

Source: Estação Meteorológica da Embrapa Terras Baixas, Capão do Leão-RS.

The variables analyzed were soybean yield in competition with the volunteer corn populations and the ETL in function of yield expected, control cost, soybean price, and control efficiency. For the soybean yield, the total plot area $\left(2 \mathrm{~m}^{2}\right)$ was harvested and subjected to grain cleaning and drying at $13 \%$ moisture, and the yield $\left(\mathrm{kg} \mathrm{ha}^{-1}\right)$ was obtained after weighing the grains on an analytical balance.
The percentage of soybean yield losses was calculated for each population level and compared with the control (without the presence of volunteer corn plants) according to the equation:

Yield loss $(\%)=[(\mathrm{Ra}-\mathrm{Rb}) / \mathrm{Ra}] \times 100$ equation (1)

where: $R a$ and $R b$ : correspond to crop yield without and with the presence of volunteer corn plant, respectively. 
The relationship between the percentage of soybean yield losses in each population of volunteer corn was calculated using the nonlinear regression model derived from the rectangular hyperbola (equation 2) proposed by Cousens (1985).

$$
\mathrm{YL}=[\mathrm{i} * \mathrm{X} /(1+(\mathrm{i} / \mathrm{a}) * \mathrm{X})]
$$

equation (2)

where: $Y L=$ yield loss $(\%) ; X=$ population of volunteer corn; $i$ and $a=$ yield loss (\%) for each unit of the competing plant when the value of the variable approaches zero and when it tends to infinity, respectively.

The ETL used the parameter $i$ obtained from equation 2 (COUSENS, 1985) and the equation adapted from Lindquist and Kropff (1996):

$\mathrm{ETL}=[\mathrm{Cc} /(\mathrm{P} * \mathrm{R} \times(\mathrm{i} / 100) *(\mathrm{H} / 100))]$ equation (3)

where: $E T L=$ economic threshold level (plants $\mathrm{m}^{-2}$ ); $C c=$ control cost (herbicide + application, in dollars ha $^{-1}$ ); $P=$ soybean price (dollars $\mathrm{kg}^{-1}$ of the grains); $R=$ soybean yield $\left(\mathrm{kg} \mathrm{ha}^{-1}\right) ; i=$ soybean yield losses (\%) per unit of volunteer corn plants when the population level approaches zero and; $H=$ efficiency of the herbicide $(\%)$.

The ETL considered four reference values based on data from the last 10 years. The yield of soybean in Rio Grande do Sul State varied from 2000 to $3500 \mathrm{~kg} \mathrm{ha}^{-1}$ (CONAB, 2017), the quotations ranged from 10 to 40 dollars for $60 \mathrm{~kg}$ bags (BANCO CENTRAL O BRASIL, 2017). The control costs considered values between 20 to 80 dollars $\mathrm{ha}^{-1}$ based on the glyphosate spray at a dosage rate of $1080 \mathrm{~g}$ ea. ha ${ }^{-1}$ combined with an ACCase inhibitor herbicide added to the application cost, and the efficiency of the herbicide was established at values of 70, 80, 90 and $100 \%$ of control.

Data adjustment to the model was performed with Proc Nlin from the statistical analysis system program (SAS, 1989) with 5\% significance $(\mathrm{p} \leq 0.05)$ using the Gauss-Newton method, which enables to estimate the values of the parameters by the sum of the squared deviations from observations in relation to the adjusted values considering the lower residual mean square (RMS) (RATKOWSKY, 1983).

\section{Chemical control of volunteer corn in different phenological stages}

The field experiment was conducted during 2014/15 agricultural year in the experimental area of the Brazilian Agricultural Research Corporation localized in Passo Fundo-RS municipality on classified soil typical dystrophic Red Latosol belonging to the Passo Fundo Mapping Unit (EMBRAPA, 2013). The soil chemical analysis exhibited water $\mathrm{pH}=5.1 ; \mathrm{CTC}_{\mathrm{pH}}=6.7 \mathrm{cmolc} \mathrm{dm}^{-3}$; $\mathrm{Al}^{3+}=3.1 \mathrm{cmolc} \mathrm{dm}{ }^{-3} ; \mathrm{Ca}^{+2}=6.6$ mmolc dm${ }^{-3} ; \mathrm{Mg}^{+2}=$ $2.7 \mathrm{cmolc} \mathrm{dm}^{-3} ; \mathrm{K}^{+}=0.23 \mathrm{mg} \mathrm{dm}{ }^{-3} ; \mathrm{P}=9.9 \mathrm{~g} \mathrm{dm}^{-3}$; clay $=61 \%$ and $1.5 \%$ of organic matter. The plots were arranged in a randomized block design with three replicates where each experimental unit was sown in a total area of $12 \mathrm{~m}^{2}$ using a population of six plants $\mathrm{m}^{-1}$ and rows spaced at $0.45 \mathrm{~m}$ from each other. The emergence of volunteer corn occurred four days after sowing and, the environment conditions during the development the volunteer crop are show in Figure 2.

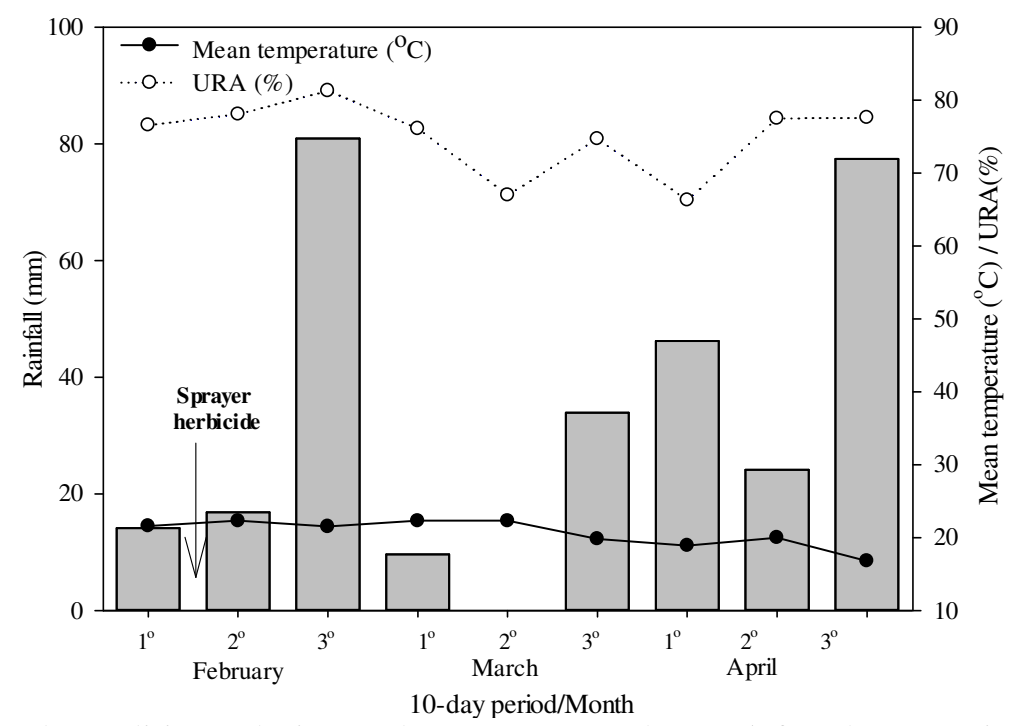

Figure 2. Environmental conditions during February to March 2015 for the experiment of volunteer corn control in different phenological stage.

Source: Estação Meteorológica da Embrapa Trigo, Passo Fundo-RS. 
The treatments were arranged in factorial design $(3 \times 9+1)$ where factor $A$ was the differential phenological stages of volunteer corn $\left(\mathrm{V}_{2}-\mathrm{V}_{3} ; \mathrm{V}_{4}-\mathrm{V}_{5}\right.$ and $\left.\mathrm{V}_{6}-\mathrm{V}_{8}\right)$ and, factor $\mathrm{B}$ was the ACCase inhibiting herbicides alone or mixed with glyphosate compared to the treatment without herbicide. The rates of each herbicide were glyphosate $(1080 \mathrm{~g}$ ea. $\left.\mathrm{ha}^{-1}\right)$, clethodim (84 g ai. ha $\left.{ }^{-1}\right)$, sethoxydim (230 g ai. ha $\left.{ }^{-1}\right)$, haloxyfop-p-methyl $\left(49.8 \mathrm{~g}\right.$ ai. ha $\left.{ }^{-1}\right)$ and fluazifop-p-buthyl (150 g ai. ha $\left.{ }^{-1}\right)$. The spray of the herbicides was performed with a $\mathrm{CO}_{2}$ backpack sprayer equipped with four TeeJet TTi 110.15 spray nozzles, spaced at $0.5 \mathrm{~m}$, and calibrated to deliver $120 \mathrm{~L} \mathrm{ha}^{-1}$ of spray volume. The meteorological conditions during the herbicide application were mean temperature of $25^{\circ} \mathrm{C}, 64 \%$ relative air humidity, and wind speeds of $1.2 \mathrm{~m} \mathrm{~s}^{-1}$.

The control of volunteer corn plants was evaluated at seven, 14 and 21 days after application (DAA) using the percentage scale from $0 \%$ to $100 \%$, where $0 \%$ means is no control and, $100 \%$ complete control of all weeds at the time of observation compared to the untreated control. The data obtained were analyzed for normality by Shapiro-Wilk test and then subjected to analysis of variance and, the means were compared by Tukey`s test $(\mathrm{p} \leq 0.05)$.

\section{RESULTS AND DISCUSSION}

\section{Economic threshold level}

The analysis of variance demonstrated significant effect of volunteer corn populations on soybean yield when in competition, with suitable adjustment of the data to the hyperbolic model proposed (Figure 3). Based on the $i$ parameter ( $\%$ yield loss of soybean per volunteer corn plant) was evidenced highly competitive potential in the NA5909 Roundup Ready soybean with yield reduction of $17 \%$ for each plant (Figure 3). Similar results have been observed for volunteer corn in soybean yield with losses from 15 to $20 \%$ per corn plant $\mathrm{m}^{-2}$ in United States of America fields (MARQUARDT et al., 2012). Higher competitive ability occurs due to rapid initial growth and higher height of the corn plant compared to the soybean causing shading, physiological and morphological alterations, and yield reduction (CHADAL; JHALA, 2016).

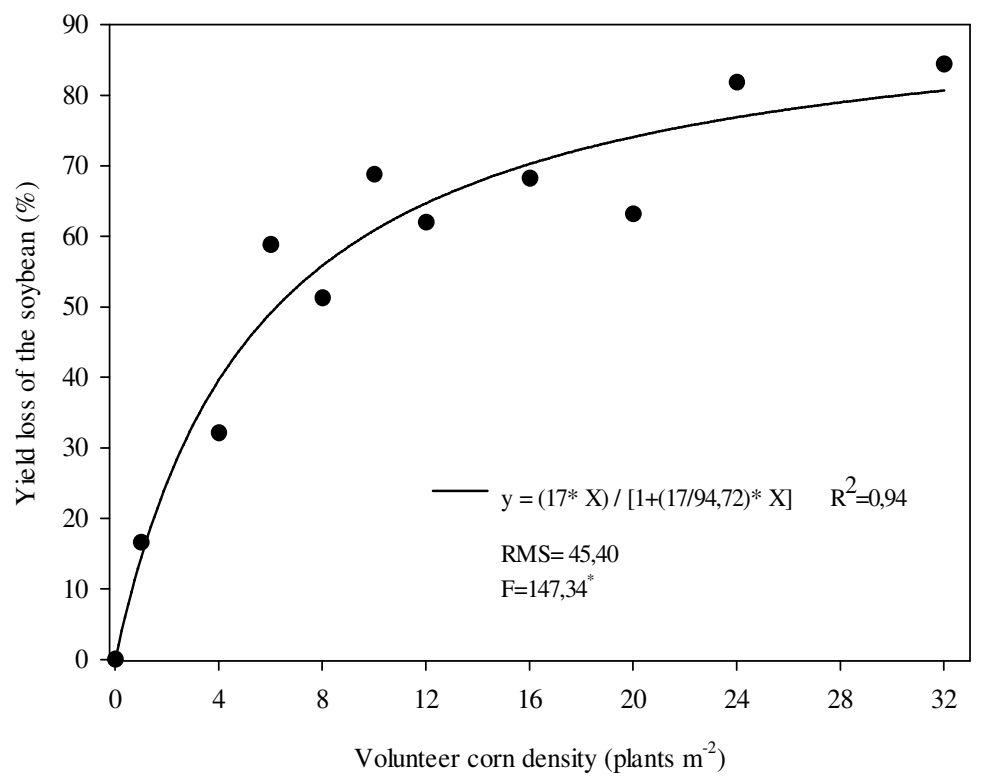

Figure 3. Yield loss (\%) in NA5909 Roundup Ready soybean in function of the differential population competition of volunteer corn. UFPel/FAEM, Pelotas-RS, 2017. RMS: Residual mean square; ${ }^{*}$ Significant at $5 \%$ probability.

For the a parameter of the model, the $94.72 \%$ value obtained indicates that the increase in the volunteer corn population may cause yield losses of approximately $100 \%$. Similar results demonstrated that the increase in corn density can be considered a highly competitive weed which reduces the yield by more than $60 \%$, depending on the population and the soybean cultivar used
(MARQUART et al., 2012; ALMS et al., 2016). In another study, volunteer corn plants in competition with soybean originating from seeds or clumps showed losses greater than $75 \%$ to 16 corn plants $\mathrm{m}^{-}$ 2 and, greater than $90 \%$ when in competition with four clumps $\mathrm{m}^{-2}$ (PIASECKI et al., 2018).

The suitable adjustment of the data to the hyperbolic model allows to evaluate the weed 
competition in different crops and enables the calculation of the ETL (AGOSTINETTO et al., 2010). The ETL ranged from 0.14 to 0.78 plants $\mathrm{m}^{-2}$ depending on the parameter used, equivalent to $5 \%$ of the soybean yield based on the mean value of each parameter (Figure 4). Considering the control cost obtained, the ETL ranged from 0.14 to 0.56 plants $\mathrm{m}^{-2}$ in the lower and higher costs, respectively (Figure 4A). Studies evaluating the control cost for ETL determination of Urochloa plantaginea and Ipomoea nil in the common bean found that low populations are enough to justify the control (VIDAL et al., 2010), which is similar to that found in the present study. Therefore, the greater the control cost, the higher the ETL of volunteer corn in the soybean crop. Although the ETL can generate information for control decision making, a lack of stability of the economic variables including the control costs and soybean price, might lead to changes in the ETL over time (KALSING; VIDAL, 2010).

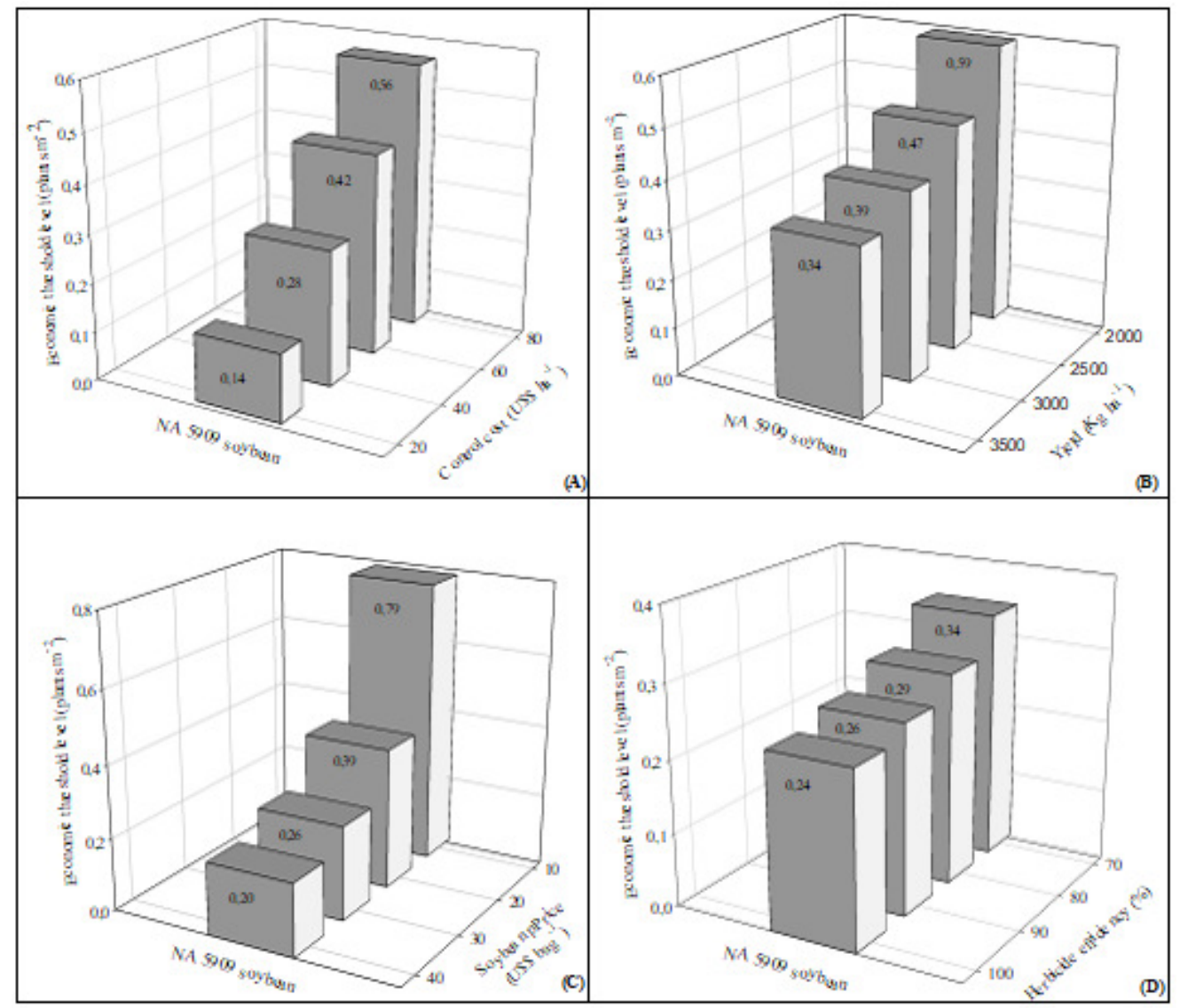

Figure 4. Economic threshold level of volunteer corn (plants $\mathrm{m}^{-2}$ ) on NA 5909 Roundup Ready soybean in function of control cost (A), yield (B), soybean price (C) and herbicide efficiency (D) for corn management. UFPel/FAEM, Pelotas-RS, 2017.

The ETL values in function of the expected soybean yield ranged from 0.34 to 0.59 plants $\mathrm{m}^{-2}$ of volunteer corn (Figure 4B). In a previous study that analyzed the competition of soybean with the weed Bidens pilosa, the ETL ranged from 0.4 to 33 plants $\mathrm{m}^{-2}$ where the time of emergence of the weed compared to the crop and the yield also influencing the ETL (RIZZARDI et al., 2003). For the ETL as a function of soybean price, the control should be performed for a population level ranging from 0.2 to 0.78 plants $\mathrm{m}^{-2}$ (Figure 4C).

Although there is variation in the ETL, independent of the situation, the ETL was lower than one plant $\mathrm{m}^{-2}$ in the present study, demonstrating higher competitive capacity of volunteer corn in reducing the soybean yield. In this way, the lower the price paid per soybean bag, the greater will be the number of volunteer corn plants needed to reach the ETL and make up for the control. Similar results were obtained in rice where the interference and ETL of Echinochloa sp. as a function of plant arrangement varied with the price paid, with the ETL being inversely proportional (AGOSTINETTO et al., 2010). Thus, higher crop yields and prices lead to lower ETL, supporting the adoption of control by farmers. 
The ETL as a function of herbicide effectiveness demonstrated that control levels above $70 \%$ are required for populations of volunteer corn with less than 0.34 plants $\mathrm{m}^{-2}$, demonstrating that the ETL is inversely proportional to herbicide effectiveness (Figure 4D). These results are in agreeance with the ETL found in Echinochloa $s p$. where the values ranged from 0.20 to 2.3 plants $\mathrm{m}^{-2}$ depending on herbicide efficiency (GALON et al., 2007). Therefore, the adoption of control is economically viable when populations of volunteer corn are lower than one plant $\mathrm{m}^{-2}$ in Roundup Ready soybean crops.

\section{Chemical control of volunteer corn in different phenological stages}

The results of chemical control demonstrated significant interaction between the herbicides treatments and different phenological stages of volunteer corn for all evaluated times, with higher effectiveness for the application at $\mathrm{V}_{2}-\mathrm{V}_{3}$ stage (Table 1).

Table 1. Control of volunteer corn in differential phenological stages at seven, 14 and 21 days after application with different ACCase inhibitor herbicides alone or mixed with glyphosate. Pelotas-RS, 2017.

\begin{tabular}{|c|c|c|c|c|c|c|c|}
\hline \multirow{2}{*}{ Herbicide treatments } & \multirow{2}{*}{$\begin{array}{c}\text { Rate } \\
\mathrm{g} \text { ai/ae } \mathrm{ha}^{-1}\end{array}$} & \multicolumn{6}{|c|}{7 DAA } \\
\hline & & \multicolumn{2}{|c|}{$\mathrm{V}_{2}-\mathrm{V}_{3}$} & \multicolumn{2}{|c|}{$\mathrm{V}_{4}-\mathrm{V}_{5}$} & \multicolumn{2}{|c|}{$\mathrm{V}_{6}-\mathrm{V}_{8}$} \\
\hline Control & - & 0 & $\mathrm{Ca}$ & 0 & $\mathrm{Da}$ & 0 & $\mathrm{Ea}$ \\
\hline Glyphosate & 1080 & 0 & $\mathrm{Ca}$ & 0 & $\mathrm{Da}$ & 0 & $\mathrm{Ea}$ \\
\hline Clethodim & 84 & 98 & $\mathrm{Aa}$ & 83 & $\mathrm{Bb}$ & 22 & Dc \\
\hline Sethoxydim & 230 & 82 & $\mathrm{Ba}$ & 65 & $\mathrm{Cb}$ & 27 & Dc \\
\hline Haloxyfop & 49.8 & 100 & $\mathrm{Aa}$ & 93 & Aa & 47 & $\mathrm{Cb}$ \\
\hline Fluazifop & 150 & 95 & $\mathrm{Aa}$ & 77 & $\mathrm{Cb}$ & 55 & $\mathrm{Cc}$ \\
\hline Glyphosate+clethodim & $1080+84$ & 98 & $\mathrm{Aa}$ & 87 & $\mathrm{Ab}$ & 82 & $\mathrm{Ab}$ \\
\hline Glyphosate+sethoxydim & $1080+230$ & 97 & $\mathrm{Aa}$ & 73 & $\mathrm{Cb}$ & 58 & $\mathrm{Cc}$ \\
\hline Glyphosate+haloxyfop & $1080+49.8$ & 100 & Aa & 90 & $\mathrm{Ab}$ & 72 & $\mathrm{Bc}$ \\
\hline Glyphosate+fluazifop & $1080+150$ & 100 & $\mathrm{Aa}$ & 80 & $\mathrm{Bb}$ & 80 & $\mathrm{Ab}$ \\
\hline V.C. $(\%)$ & - & \multicolumn{6}{|c|}{9,4} \\
\hline \multirow{2}{*}{ Herbicide treatments } & \multirow{2}{*}{$\begin{array}{c}\text { Rate } \\
\text { g ai/ae ha }{ }^{-1}\end{array}$} & \multicolumn{6}{|c|}{ 14 DAA } \\
\hline & & \multicolumn{2}{|c|}{$\mathrm{V}_{2}-\mathrm{V}_{3}$} & \multicolumn{2}{|c|}{$\mathrm{V}_{4}-\mathrm{V}_{5}$} & \multicolumn{2}{|c|}{$\mathrm{V}_{6}-\mathrm{V}_{8}$} \\
\hline Control & - & 0 & $\mathrm{Ba}$ & 0 & $\mathrm{Ca}$ & 0 & $\mathrm{Ea}$ \\
\hline Glyphosate & 1080 & 0 & $\mathrm{Ba}$ & 0 & $\mathrm{Ca}$ & 0 & $\mathrm{Ea}$ \\
\hline Clethodim & 84 & 100 & $\mathrm{Aa}$ & 100 & $\mathrm{Aa}$ & 22 & $\mathrm{Db}$ \\
\hline Sethoxydim & 230 & 98 & Aa & 60 & $\mathrm{Bb}$ & 47 & $\mathrm{Cc}$ \\
\hline Haloxyfop & 49.8 & 100 & $\mathrm{Aa}$ & 100 & $\mathrm{Aa}$ & 95 & Aa \\
\hline Fluazifop & 150 & 100 & Aa & 100 & $\mathrm{Aa}$ & 87 & $\mathrm{Bb}$ \\
\hline Glyphosate+clethodim & $1080+84$ & 100 & $\mathrm{Aa}$ & 100 & $\mathrm{Aa}$ & 80 & $\mathrm{Bb}$ \\
\hline Glyphosate+sethoxydim & $1080+230$ & 100 & $\mathrm{Aa}$ & 100 & $\mathrm{Aa}$ & 68 & $\mathrm{Cb}$ \\
\hline Glyphosate+haloxyfop & $1080+49.8$ & 100 & $\mathrm{Aa}$ & 100 & Aa & 92 & $\mathrm{Aa}$ \\
\hline Glyphosate+fluazifop & $1080+150$ & 100 & Aa & 100 & $\mathrm{Aa}$ & 91 & $\mathrm{Aa}$ \\
\hline V.C. $(\%)$ & - & \multicolumn{6}{|c|}{5,9} \\
\hline \multirow{2}{*}{ Herbicide treatments } & Rate & \multicolumn{6}{|c|}{21 DAA } \\
\hline & $\mathrm{g}$ ai/ae ha ${ }^{-1}$ & \multicolumn{2}{|c|}{$\mathrm{V}_{2}-\mathrm{V}_{3}$} & \multicolumn{2}{|c|}{$\mathrm{V}_{4^{-}}-\mathrm{V}_{5}$} & \multicolumn{2}{|c|}{$\mathrm{V}_{6}-\mathrm{V}_{8}$} \\
\hline Control & - & 0 & $\mathrm{Ba}$ & 0 & $\mathrm{Ca}$ & 0 & $\mathrm{Da}$ \\
\hline Glyphosate & 1080 & 0 & $\mathrm{Ba}$ & 0 & $\mathrm{Ca}$ & 0 & $\mathrm{Da}$ \\
\hline Clethodim & 84 & 100 & $\mathrm{Aa}$ & 100 & Aa & 23 & $\mathrm{Cb}$ \\
\hline Sethoxydim & 230 & 98 & $\mathrm{Aa}$ & 88 & $\mathrm{Bb}$ & 70 & $\mathrm{Bc}$ \\
\hline Haloxyfop & 49.8 & 100 & $\mathrm{Aa}$ & 100 & Aa & 98 & $\mathrm{Aa}$ \\
\hline Fluazifop & 150 & 100 & $\mathrm{Aa}$ & 100 & $\mathrm{Aa}$ & 92 & $\mathrm{Ab}$ \\
\hline Glyphosate+clethodim & $1080+84$ & 100 & $\mathrm{Aa}$ & 100 & $\mathrm{Aa}$ & 100 & $\mathrm{Aa}$ \\
\hline Glyphosate+sethoxydim & $1080+230$ & 100 & $\mathrm{Aa}$ & 100 & $\mathrm{Aa}$ & 72 & $\mathrm{Bb}$ \\
\hline Glyphosate+haloxyfop & $1080+49.8$ & 100 & $\mathrm{Aa}$ & 100 & $\mathrm{Aa}$ & 98 & $\mathrm{Aa}$ \\
\hline Glyphosate+fluazifop & $1080+150$ & 100 & $\mathrm{Aa}$ & 100 & $\mathrm{Aa}$ & 93 & $\mathrm{Aa}$ \\
\hline V.C. (\%) & - & & & & & & \\
\hline
\end{tabular}


At seven DAA, the control was greater than $95 \%$ in $\mathrm{V}_{2}-\mathrm{V}_{3}$ stage for all herbicides, except for glyphosate and sethoxydim where the control was $0 \%$ and $82 \%$, respectively (Table 1 ). Similar results were obtained for the application of haloxyfop and clethodim herbicides at the rate of 62 and $84 \mathrm{~g}$ ai. $\mathrm{ha}^{-1}$, respectively, with control levels of volunteer corn being greater than $97 \%$ at seven DAA (MACIEL et al., 2013). For spraying during the $\mathrm{V}_{4^{-}}$ $\mathrm{V}_{5}$ phenological stage, only haloxyfop alone or mixed with glyphosate provided a control level above $90 \%$ and, for the $\mathrm{V}_{6}-\mathrm{V}_{8}$ stage, the best herbicides were the mixture of glyphosate with clethodim and haloxyfop where the control levels were $82 \%$ and $80 \%$, respectively. The reduced control observed in advanced phenological stages, can be attributed to a greater amount of wax and cuticle thickness, hindering the penetration of herbicides (LIMA et al., 2011).

For the evaluation at $14 \mathrm{DAA}$, the results demonstrated that the herbicides clethodim, haloxyfop and fluazifop applied alone or mixed with glyphosate provided control levels above $98 \%$ for $\mathrm{V}_{2}-\mathrm{V}_{3}$ and $\mathrm{V}_{4}-\mathrm{V}_{5}$ phenological stages, except for the alone spraying of sethoxydim in $\mathrm{V}_{4}-\mathrm{V}_{5}$ stage where the control was only $60 \%$ (Table 1 ). Higher control in $\mathrm{V}_{6}-\mathrm{V}_{8}$ phenological stage was obtained with the application of haloxyfop alone reaching $95 \%$ of the control and for the mixtures of glyphosate with fluazifop and haloxyfop where the control was $91 \%$ and $92 \%$ at 14 DAA, respectively (Table 1). In corn, the inhibition of ACCase can occur in two catalytic subunits (ACCase I and II) with approximately $80 \%$ of the total activity of the enzyme located on subunit I that shows higher sensitivity to inhibition, in particular, to the aryloxyphenoxypropionates group (PRADO et al., 2000).

At 21 DAA, except for clethodim, all treatments showed control levels greater than $98 \%$ for applications until the $\mathrm{V}_{5}$ phenological stage (Table 1). Similar results were obtained for the control of volunteer corn with ACCase enzyme inhibitors where the effectiveness was higher for application in initial stages and lower than five leaves (CHAHAL et al., 2014). Furthermore, a strong reduction in the control levels of clethodim was evidenced for the $\mathrm{V}_{6}-\mathrm{V}_{8}$ phenological stage where the control was $23 \%$ and $72 \%$ when applied alone or mixed with glyphosate, respectively (Table 1). In the $V_{6}$ stage corn, the growing point of the plant is above the soil surface, which occurs simultaneously with the beginning of floral differentiation and increased lignification of the cellular wall. This might result in low uptake of the herbicide and reduced control of volunteer corn plants (MARQUARDT; JOHNSON, 2013). Similar results were reported for late applications in Digitaria insularis where the reduction of control was linked to the decreased absorption, increase of metabolism and detoxification of the molecule (CARVALHO et al., 2012). Moreover, the increase of herbicide effectiveness observed for fluazifop and haloxyfop may have occurred due to higher absorption and translocation, since these molecules are formulated as esters and may penetrate the cell more easily (NAYLOR, 2002) and/or, possible synergic effects when mixed with glyphosate.

\section{CONCLUSIONS}

The volunteer corn was highly competitive on NA 5909 Roundup Ready soybean with a yield reduction of $17 \%$ for each plant per $\mathrm{m}^{2}$ while the ETL ranged from 0.14 to 0.78 plants $\mathrm{m}^{-2}$ depending of the parameter used.

The control of ACCase inhibitor herbicides applied alone or mixed with glyphosate was higher at the $\mathrm{V}_{2}-\mathrm{V}_{3}$ phenological stage.

The reduction of control occurred for the late applications where control levels above $87 \%$ were only obtained for the herbicides fluazifop and haloxyfop alone or mixed with glyphosate for the $\mathrm{V}_{6}-\mathrm{V}_{8}$ phenological stage at 14 and 21 DAA.

\section{ACKNOWLEDGEMENTS}

The authors thank the coordination of the Brazilian Federal Agency for Post-Graduate Education for the scholarship of the first author and the Embrapa/Monsanto Partnership.

RESUMO: O uso sucessivo de culturas "Roundup Ready" pode dificultar o manejo de plantas voluntárias originadas de sementes perdidas durante a colheita. Na soja, plantas de milho voluntário podem apresentar elevada interferência e causar redução da produtividade dependendo da sua densidade. O objetivo do estudo foi quantificar o nível de dano econômico (NDE) na soja em função da competição de milho voluntário e avaliar o controle químico em diferentes estádios fenológicos de desenvolvimento. Os experimentos de NDE e controle químico foram conduzidos a campo, em delineamento inteiramente e blocos casualizados com uma e três repetições, respectivamente. As variáveis analisadas foram a produtividade e o NDE em função da competição das diferentes populações de milho voluntário (zero; um; dois; quatro; seis; oito; 10; 12; 16; 20; 24 e 32 plantas $\mathrm{m}^{-2}$ ) e o controle químico com herbicidas inibidores da enzima 
acetil CoA carboxilase (ACCase) isolados ou misturados com o glifosato em diferentes estádios fenológicos de desenvolvimento $\left(\mathrm{V}_{2}-\mathrm{V}_{3} ; \mathrm{V}_{4}-\mathrm{V}_{5}\right.$ e $\left.\mathrm{V}_{6}-\mathrm{V}_{8}\right)$ que foram avaliados aos sete, 14 e 21 dias após a aplicação (DAA). Os resultados demonstraram maior potencial competitivo do milho voluntário onde a presença de uma planta $\mathrm{m}^{-2}$ reduziu a produtividade da soja em $17 \%$. O NDE variou de 0,14 a 0,78 plantas $\mathrm{m}^{-2}$ e o controle do milho voluntário deve ser realizado em populações baixas. $\mathrm{O}$ uso de herbicidas inibidores da ACCase isolados ou misturados com o glifosato proporcionaram controle superior $85 \%$ no estádio fenológico $\mathrm{V}_{2}-\mathrm{V}_{3}$ independente do período avaliado. A eficácia de todos os herbicidas decresceu com o atraso da aplicação com um nível de controle acima de $87 \%$, no estádio fenológico $\mathrm{V}_{6}$ - $\mathrm{V}_{8}$, obtido apenas para os herbicidas fluazifope e haloxifope isolado ou em mistura com o glifosato aos 14 e 21 dias após aplicação.

PALAVRAS-CHAVE: Herbicidas alternativos. Competição. Nível de dano. Glycine max Zea mays

\section{REFERENCES}

AGOSTINETTO, D.; GALON, L.; SILVA, J. M. B. V.; TIRONI, S. P.; ANDRES, A. Interferência e nível de dano econômico de capim-arroz sobre o arroz em função do arranjo de plantas da cultura. Planta Daninha, Viçosa, v. 28, n.spe, p. 993-1003, 2010. http://dx.doi.org/10.1590/S0100-83582010000500007

ALMS, J.; MOECHNIG, M.; VOS, D.; CLAY, S. A. Yield loss and management of volunteer corn in soybean. Weed Technology, Fayetteville, v. 30, n. 1, p. 254-262, 2016. https://doi.org/10.1614/WT-D-15-00096.1

BANCO CENTRAL DO BRASIL. Dólar americano. Disponível em:

http://www4.bcb.gov.br/pec/taxas/batch/taxas.asp?id=txdolar. Acesso em: jan. 2017.

BENBROOK, C. M. Trends in glyphosate herbicide use in the United States and globally. Environmental Sciences Europe, Aachen, v. 28, n. 10, p. 1-15, 2016. https://doi.org/10.1186/s12302-016-0070-0

CARVALHO, L. B.; ALVES, P. L. C. A.; GONZALEZ-TORRALVA, F.; CRUZ-HIPOLITO, H. E.; ROJANO-DELGADO, A. M.; PRADO, R.; GIL-HUMANES, J.; BARRO, F.; CASTRO, M. D. L. Pool of resistance mechanisms to glyphosate in Digitaria insularis. Journal of Agricultural and Food Chemistry, Washington, v. 60, n. 2, p. 615-622, 2012. http://pubs.acs.org/doi/abs/10.1021/jf204089d

CHADAL, S. P.; JHALA, A. J. Impact of glyphosate-resistant volunteer corn (Zea mays L.) density, control timing, and late-season emergence on yield of glyphosate-resistant soybean (Glycine max L.). Crop Protection, Copenhagen, v. 81, n. 3, p. 38-42, 2016. https://doi.org/10.1016/j.cropro.2015.11.015

CHAHAL, S. P.; KRUGER, G.; BLANCO-CANQUI, H.; JHALA, A. J. Efficacy of pre-emergence and postemergence soybean herbicides for control of glufosinate, glyphosate and imidazolinone-resistant volunteer corn. Journal of Agricultural Science, Toronto, v. 6, n. 8, p. 131-140, 2014.

http://dx.doi.org/10.5539/jas.v6n8p131

CONAB. Companhia Nacional De Abastecimento. Acompanhamento da safra brasileira: grãos, quarto levantamento, 2017. Disponível em: http://www.conab.gov.br Acesso em: fev. 2017.

COUSENS, R. D. An empirical model relating crop yield to weed and crop density and a statistical comparison whit other models. Journal of Agricultural Sciences, Toronto, v. 105, n. 3, p. 513-521, 1985. https://doi.org/10.1017/S0021859600059396

PRADO, R.; GONZÁLEZ-GUTIÉRREZ, J.; MENÉNDEZ, J.; GASQUEZ, J.; GRONWALD. J. W.; GIMÉNEZ-ESPINOSA, R. Resistance to acetyl CoA carboxylase-inhibiting herbicides in Lolium multiflorum. Weed Science, Athens, v. 48, n. 3, p. 311-318, 2000. https://doi.org/10.1614/00431745(2000)048[0311:RTACCI]2.0.CO;2 
DEEN, W.; HAMILL, A.; SHROPSHIRE, C.; SOLTANI, N.; SIKKEMA, P. Control of volunteer glyphosateresistant corn (Zea mays) in glyphosate-resistant soybean. Weed Technology, Fayetteville, v. 20, n. 1, p. 261266, 2006. https://doi.org/10.1614/WT-02-128.1

EMBRAPA. Centro Nacional de Pesquisa de Solos. Sistema brasileiro de classificação de solos. 3.ed. Rio de Janeiro: Embrapa Solos, 2013. 353p.

EMBRAPA- Empresa Brasileira de Pesquisa Agropecuária. Indicações técnicas para a cultura da soja no Rio Grande do Sul e em Santa Catarina, safras 2014/2015 e 2015/2016. Pelotas: Embrapa Clima Temperado, 2014. 124p.

GALON, L.; AGOSTINETTO, D.; MORAES, P. V. D.; DAL MAGRO, T.; PANOZZO, L. E.; BRANDOLT, R. R.; SANTOS, L. S. Níveis de dano econômico para decisão de controle de capim-arroz (Echinochloa spp.) em arroz irrigado (Oryza sativa). Planta Daninha, Viçosa, v. 25, n. 4, p. 709-718, 2007. http://dx.doi.org/10.1590/S0100-83582007000400007

KALSING, A.; VIDAL, R. A. Nível de dano econômico aplicado à herbologia: revisão. Pesticidas: Revista de Ecotoxicologia e Meio Ambiente, Curitiba, v. 20, n. 1, p. 43-56, 2010.

http://dx.doi.org/10.5380/pes.v20i1.20476

LIMA, D. B. C.; SILVA, A. G.; BARROSO, A. L.; PROCÓPIO, S. O.; DAN, H. Controle químico de plantas voluntárias de soja Roundup Ready ${ }^{\circledR}$ em diferentes estádios de desenvolvimento. Revista Caatinga, Mossoró, v. 24, n. 3, p. 64-70, 2011.

LINDQUIST, J. L.; KROPFF, M. J. Applications of an ecophysiological model for irrigated rice (Oryza sativa) - Echinochloa competition. Weed Science, Athens, v. 44, n. 1, p. 52-56, 1996.

http://www.jstor.org/stable/4045782

MACIEL, C. D. G. ZOBIOLE, L. H. S.; SOUZA, J. I.; HIROOKA, E.; LIMA, L. G. N. V.; SOARES, C. R. B.; PIVATTO, R. A. D.; FUCHS, G. M.; HELVIG, E. O. Eficácia do herbicida haloxyfop R (GR-142) isolado e associado ao 2,4-D no controle de híbridos de milho $\mathrm{RR}^{\circledR}$ voluntário. Revista Brasileira de Herbicidas, Londrina, v. 12, n. 2, p. 112-123, 2013. http://dx.doi.org/10.7824/rbh.v12i2.244

MARQUARDT, P. KRUPKE, C.; JOHNSON, W. G. Competition of transgenic volunteer corn with soybean and the effect on western corn rootworm emergence. Weed Science, Athens, v. 60, n. 2, p. 193-198, 2012. https://doi.org/10.1614/WS-D-11-00133.1

MARQUARDT, P. T.; JOHNSON, W. G. Influence of clethodim application timing on control of volunteer corn in soybean. Weed Technology, Fayetteville, v. 27, n. 4, p. 645-648, 2013. http://dx.doi.org/10.1614/WTD-12-00188.1

NAYLOR, R. E. L. Weed Management Handbook, 9.ed. Blackwell: John Wiley, 2002. 432p.

OWEN, M. D. K. Current use of transgenic herbicide-resistant soybean and corn in the USA. Crop Protection, Copenhagen, v. 19, n. 9, p. 765-771, 2000. https://doi.org/10.1016/S0261-2194(00)00102-2

PADGETTE, S. R.; RE, D. B.; BARRY, G. F.; EICHHOLTZ, D. E.; DELANNAY, X.; FUCHS, R. L.; KISHORE, G. M.; FRALEY, R. T. New weed control opportunities: Development of soybeans with a Roundup Ready ${ }^{\mathrm{TM}}$ gene. In: DUKE, S. O. Herbicide resistant crops. 1.ed Boca Raton: CRC Press, p. 53-84, 1996.

PETTER, F.A.; PROCÓPIO, S.O.; CARGNELUTTI FILHO, A.; BARROSO, A.L.L.; PACHECO, L.P. Manejo de herbicidas na cultura da soja Roundup Ready ${ }^{\circledR}$. Planta Daninha, Viçosa, v.25, n.3, p.557-566, 2007. http://dx.doi.org/10.1590/S0100-83582007000300015 
PETTER, F. A. SIMA, V. M.; FRAPORTI, M. B.; PEREIRA, C. S.; PROCÓPIO, S. O.; SILVA, A. F. Volunteer $\mathrm{RR}^{\circledR}$ corn management in Roundup Ready ${ }^{\circledR}$ soybean corn succession system. Planta Daninha, Viçosa, v. 33, n. 1, p. 119-128, 2015. http://dx.doi.org/10.1590/S0100-83582015000100014

PIASECKI, C.; RIZZARDI, M. A.; SCHWADE, D. P.; TRES, M.; SARTORI, J. Influence of GR ${ }^{\circledR}$ volunteer corn population and origin on soybean grain yield losses. Planta Daninha, Viçosa, v. 36, e018161420, 2018. http://dx.doi.org/10.1590/s0100-83582018360100003

RATKOWSKY, David A. Nonlinear regression modeling: a unified practical approach. 1.ed. New York: Marcel Dekker, p.135-154, 1983.

RIZZARDI, M. A.; FLECK, N. G.; AGOSTINETTO, D. Nível de dano econômico como critério para controle de picão-preto em soja. Planta Daninha, Viçosa, v. 21, n. 2, p. 273-282, 2003.

http://dx.doi.org/10.1590/S0100-83582003000200013

SAS. Institute Statistical Analysis System. User's guide. Version 6. 4.ed. Carolina do Norte: SAS Institute, 1989. 846p.

TAN, S.; EVANS, R.; SINGH, B. Herbicidal inhibitors of amino acid biosynthesis and herbicide-tolerant crops. Amino Acids, Viena, v. 30, n. 2, p. 195-204, 2006.

VIDAL, R. A.; KALSING, A.; GHEREKHLOO, J. Interferência e nível de dano econômico de Brachiaria plantaginea e Ipomoea nil na cultura do feijão comum. Ciência Rural, Santa Maria, v. 40, n. 8, p. 1675-1681, 2010. http://dx.doi.org/10.1590/S0103-84782010000800001 